\title{
Management of Respiratory Distress in the Newborn
}

\author{
Surg Cdr SS Mathai*, Col U Raju+, Col M Kanitkar ${ }^{\#}$
}

MJAFI 2007; 63 : 269-272

Key Words : Respiratory distress; Newborn

\section{Introduction}

$\mathrm{R}$ espiratory distress is a common emergency responsible for $30-40 \%$ of admissions in the neonatal period [1]. A working diagnosis should be made in the first few minutes of seeing the baby and immediate lifesaving measures should be undertaken till further management plans are drawn up.

Respiratory distress in the neonate is diagnosed when one or more of the following is present; tachypnoea or respiratory rate of more than $60 /$ minute, retractions or increased chest in drawings on respirations (subcostal, intercostal, sternal, suprasternal) and noisy respiration in the form of a grunt, stridor or wheeze[1]. The distress may or may not be associated with cyanosis and desaturation on pulse oximetry. The common causes of respiratory distress in the neonate are:

1. Hyaline Membrane Disease (HMD)

2. Meconium Aspiration Syndrome (MAS)

3. Transient Tachypnoea of the Newborn (TTNB)

4. Congenital or acquired pneumonia

5. Persistent Pulmonary Hypertension of the Newborn (PPHN)

6. Air leaks

7. Congenital anomalies of upper airway (choanal atresia), gut (tracheoesophageal fistula, congenital diaphragmatic hernia) or lungs (lobar emphysema, congenital cystic adenomatoid malformation, cysts)

8. Cardiac shock or Congenital Heart Disease (CHD).

9. Haematological causes (severe anaemia, polycythaemia)

10. Neurological causes leading to hyperventilation like seizures

11. Metabolic causes- Inborn Errors of Metabolism (IEM)
Pathophysiology Unique to Newborn

Prolonged and unattended distress leads to hypoxaemia, hypercarbia and acidosis. These causes lead to pulmonary vasoconstriction and persistence of foetal circulation with right to left shunting through the ductus and foramen ovale, thereby aggravating hypoxaemia which leads to multi system organ dysfunction.

An audible grunt (forced expiratory sound) is an important sign of pulmonary pathology in the newborn indicating that the baby has a low lung volume or functional residual capacity (FRC). Breathing against a partially closed glottis increases the FRC of the baby and helps keep the alveoli patent. This is characteristically seen in a baby with HMD where surfactant deficiency tends to keep the alveoli collapsed during expiration. Indiscriminately inserting an endotracheal (ET) tube without giving positive end expiratory pressure (PEEP) to a neonate who is grunting will deprive the baby of this physiological effect and worsen rather than improve his condition. Hence any baby who is grunting should either be given continuous positive airway pressure (CPAP) or intubated and put on ventilator support, but never left to breathe spontaneously with a tube in situ.

\section{Grading of Distress Severity}

The severity of respiratory distress is assessed by Silverman- Anderson Score and Downes' Score. While the Silverman Anderson Retraction Score is more suited for preterms with HMD, the Downes' Score is more comprehensive and can be applied to any gestational age and condition. Scoring should be done at half hourly intervals and a chart maintained to determine progress (Tables 1,2). A progressively increasing $\mathrm{FiO}_{2}$ requirement to maintain a saturation of $90-92 \%$ in a preterm and 94 $96 \%$ in a term baby is also a sensitive indicator of the severity and progress of distress.

\footnotetext{
*Associate Professor, " Professor and Head (Department of Paediatrics ), Armed Forces Medical College, Pune. ${ }^{+}$Senior Advisor (Paediatrics \& Neonatology), Command Hospital (Southern Command), Pune. 
Table 1

Silverman Anderson retraction score [2]

$\begin{array}{llllll}\text { Score } & \begin{array}{l}\text { Upper } \\ \text { chest } \\ \text { retraction }\end{array} & \begin{array}{l}\text { Lower } \\ \text { chest } \\ \text { retraction }\end{array} & \begin{array}{l}\text { Xiphoid } \\ \text { retraction }\end{array} & \begin{array}{l}\text { Nasal } \\ \text { dilatation }\end{array} & \text { Grunt } \\ 0 & \begin{array}{l}\text { Synch } \\ \text { Lag on }\end{array} & \begin{array}{l}\text { Jone } \\ \text { Just }\end{array} & \begin{array}{l}\text { None } \\ \text { Just } \\ \text { visible }\end{array} & \begin{array}{l}\text { None } \\ \text { Minimal }\end{array} & \begin{array}{l}\text { None } \\ \text { Stethoscope } \\ \text { only }\end{array} \\ 2 & \text { See-Saw } & \text { Marked } & \text { Marked } & \text { Marked } & \text { Naked ear }\end{array}$

A score of $>6$ is indicative of impending respiratory failure.

Table 2

Downes' score [3]

\begin{tabular}{|c|c|c|c|c|c|}
\hline Score & $\begin{array}{l}\text { Respiratory } \\
\text { rate }\end{array}$ & Cyanosis & $\begin{array}{l}\text { Air } \\
\text { entry }\end{array}$ & Grunt & Retraction \\
\hline 0 & $<60 /$ min & Nil & Normal & None & Nil \\
\hline 1 & $\begin{array}{l}60- \\
80 / \min \end{array}$ & $\begin{array}{l}\text { In room } \\
\text { air }\end{array}$ & Mild? & $\begin{array}{l}\text { Ausc } \\
\text { with } \\
\text { stethoscop }\end{array}$ & $\begin{array}{l}\text { Mild } \\
\text { pe }\end{array}$ \\
\hline 2 & $>80 / \mathrm{min}$ & In $\geq 40 \%$ & Marked? & $\begin{array}{l}\text { Audible } \\
\text { with } \\
\text { naked ear }\end{array}$ & Moderate \\
\hline
\end{tabular}

A score of $>6$ is indicative of impending respiratory failure.

Besides assessing the severity of the distress it is essential to determine the underlying pathology for further management. For a new born baby (within few hours of birth) with respiratory distress, a quick review of the following antenatal and peripartum events including the condition at birth is a must :-

a) Were there any risk factors in the antepartum period or evidence of foetal distress prior to delivery? (Birth asphyxia or PPHN)

b) Did the mother receive antenatal steroids if it was a preterm delivery? (Antenatal steroids decrease the incidence of HMD by $50 \%$ )

c) Was there a history of premature rupture of membranes and fever? (congenital pneumonia or sepsis)

d) Was there meconium stained amniotic fluid? (MAS is a possibility)

e) A look at the antenatal ultrasonography (USG) for the amount of amniotic fluid would tell us the status of the foetal lung. (congenital anomalies of lung)

f) Was resuscitation required at birth? (resuscitation trauma/PPHN/ acidosis)

g) Did the distress appear immediately or a few hours after birth? (HMD appears earlier than pneumonia)

h) Was it related to feeding or frothing at the mouth? (tracheo-esophageal fistula or aspiration)

i) Does the distress decrease with crying? (choanal atresia).
For babies presenting later with distress we have to ask a few other questions :-

a) Is the distress associated with feed refusal and lethargy? (sepsis, pneumonia)

b) Did the distress appear slowly after starting feeds? (IEM).

c) Is there a family history of early neonatal deaths? (CHD, IEM).

The algorithm shown in Fig.1, helps in reaching a working aetiological diagnosis [4].

\section{Clinical Examination}

Clues to the likely aetiology can be picked up on examination of the neonate

1. A preterm baby weighing $<1500$ gms with retractions and grunt is likely to have HMD.

2. A term baby born through meconium stained amniotic fluid with an increase in the anteriorposterior diameter of the chest (full chest) is likely to be suffering from MAS.

3. A depressed baby with poor circulation is likely to have neonatal sepsis with or without congenital pneumonia.

4. A near term baby with no risk factors and mild distress may have TTNB.

5. An asphyxiated baby may have PPHN.

6. A growth retarded baby with a plethoric look may have polycythaemia.

7. A baby with respiratory distress should be checked for an air leak by placing a cold light source over the chest wall in a darkened room.

8. A baby presenting with tachypnoea and a cardiac murmur may have a congenital heart disease.

9. Inability to pass an 5F catheter through the nostril of a term baby is suggestive of choanal atresia.

\section{Investigations}

Essential investigations for all cases of neonatal

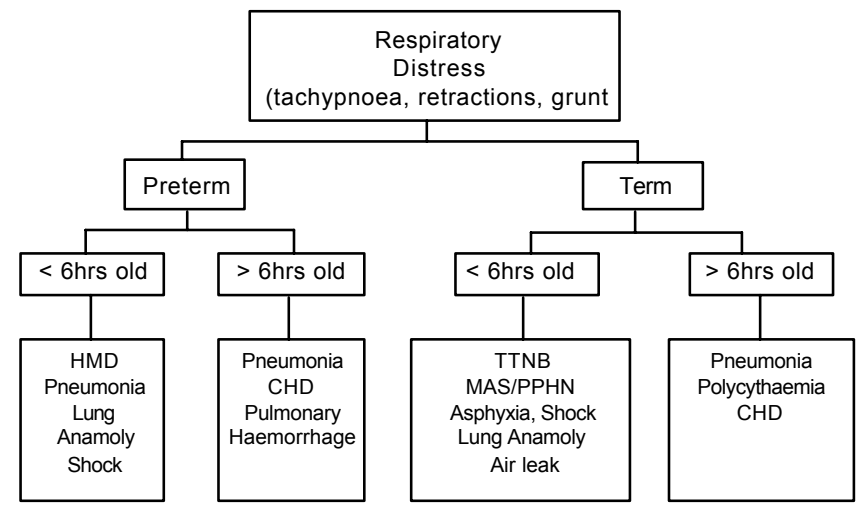

Fig. 1 : Diagnostic approach to respiratory distress 
respiratory distress include chest radiograph with an orogastric tube in situ, arterial blood gas (ABG) analysis (Table 3), sepsis screen including C-reactive protein, $\mu$ ESR, white blood cell count, peripheral smear for toxic granules, blood culture, surface swab culture (where indicated), maternal vaginal swab, blood glucose, serum calcium and central haematocrit assessment.

A score of 3 or more on the ABG indicates the need for CPAP or mechanical ventilation. A $\mathrm{pH}$ of $<7.2$ with hypercarbia ( $\mathrm{pCO} 2>60 \mathrm{~mm}$ ) or a $\mathrm{pO}_{2}<50 \mathrm{~mm} \mathrm{Hg}$ in $\mathrm{FiO}_{2}$ of 0.8 is suggestive of frank respiratory failure.

\section{Treatment}

1. Clearing of airway, ensuring adequate breathing and circulation are the first line of management. A baby in obvious respiratory distress needs to be on continuous pulse oximeter monitoring to decide when intubation and ventilation is required.

2. Warm, humidified oxygen is given with a head box, preferably with a $\mathrm{FiO}_{2}$ meter and pulse oximeter monitoring to determine the amount of oxygen required. Soft nasal cannulae may also be used to give oxygen. Small changes in $\mathrm{FiO}_{2}$ are made and monitored on the pulse oximeter. Oxygen should be given in the correct dose, as it is toxic to preterm neonates and the suggested guidelines are given in Table 4. The "30-60-90" rule is a useful bedside indicator when using the pulse oximeter. This means that at a saturation of $90 \%$ the $\mathrm{paO}_{2}$ is around $60 \mathrm{mmHg}$ and at $60 \%$ it is around $30 \mathrm{mmHg}$ in a newborn. This is due to high $\mathrm{HbF}$ in neonatal blood which causes the left shift of oxygen dissociation curve. At saturation of $90-95 \%$, the $\mathrm{paO}_{2}$ may be between 60 to $98 \mathrm{~mm} \mathrm{Hg}$ and above $95 \%$ saturation, $\mathrm{paO}_{2}$ is well above $100 \mathrm{mmHg}$.

3. Maintenance of correct temperature is essential. HMD and PPHN are aggravated by hypothermia.

Table 3

ABG score

\begin{tabular}{lcccc} 
& \multicolumn{4}{c}{ Points } \\
& 0 & 1 & 2 & 3 \\
$\mathrm{paO}_{2} \mathrm{mmHg}$ & $>60$ & $50-60$ & $<50$ & $<50$ \\
$\mathrm{pH}$ & $>7.3$ & $7.20-7.29$ & $7.1-7.19$ & $<7.1$ \\
$\mathrm{paCO}_{2} \mathrm{mmHg}$ & $<50$ & $50-60$ & $61-70$ & $>70$
\end{tabular}

Score of $>3$ suggestive of ventilatory support requirement

Table 4

Guidelines for monitoring oxygen saturation levels by pulse oximetry

$>95 \%$ Term baby, pulmonary hypertension (PPHN)

$88-94 \% \quad 28-34$ weeks preterm

$85-92 \% \quad$ Below 28 weeks gestational age
4. Fluid and electrolyte management: Electrolyte balance, fluids, calcium and glucose homeostasis are all equally important. Fluids are usually started at a minimum of $60 \mathrm{ml} / \mathrm{kg} /$ day of $10 \% \mathrm{D}$ or three fourth of daily maintenance whichever is more. This will ensure a glucose infusion rate of about $4 \mathrm{mg} / \mathrm{kg} / \mathrm{min}$ which is the minimum required for adequate glucose homeostasis. Calcium in the dose of $6-8 \mathrm{ml} / \mathrm{kg} /$ day of calcium gluconate should be added to the fluid in all preterms and term babies.

5. Maintenance of adequate haemoglobin: Any neonate with respiratory distress should have a packed cell volume (PCV) above 40\% (but less than 75\%).

6. All preterm babies with respiratory distress should be started on broad spectrum antibiotics. In term babies, decision to start antibiotics would depend on the clinical situation, but the threshold should be low.

\section{Role of Surfactant}

Surfactant is the drug of choice in a baby with HMD. This may be given either prophylactically if the baby is less than 28 weeks of gestation or within the first two hours of onset of symptoms in older babies $[7,8]$. Prophylactic surfactant is given in the labour room after the baby has been stabilized. Rescue therapy is most effective if given within the first two hours of birth. Presently both natural and synthetic surfactants are being marketed in India. Surfactant is given in a dose of $100 \mathrm{mg} / \mathrm{kg}$ through the endotracheal tube in small aliquots with intermittent bagging to prevent desaturation during administration and it should be followed by ventilatory support.

\section{Respiratory Support}

Respiratory support is given in the form of continuous positive airway pressure (CPAP) or intermittent mandatory ventilation (IMV). Short nasal or longer nasopharyngeal prongs are preferred to endotracheal CPAP as latter markedly increases the work of breathing and tires the infant. CPAP should be started early in a preterm with HMD. Indications for starting CPAP are a Downes' or Silvermann score of $>6$ at birth or a $\mathrm{FiO}_{2}$ requirement of $>0.4$ to maintain an acceptable saturation on pulse oximeter. ABG score of more than 3 is also acceptable. CPAP is a gentler form of non-invasive ventilatory support as compared to IMV [6].

IMV: Time cycled pressure limited ventilation is the modality of choice for ventilation of a neonate in respiratory failure. If patient triggered ventilation is used it is given as synchronized intermittent mandatory ventilation (SIMV) or assist control mode ventilation (ACMV). For best outcomes this should be given to babies in impending respiratory failure or failed CPAP 
rather than in complete respiratory failure [5]. Resistant apnoea is also an absolute indication. CPAP is said to have failed when the $\mathrm{FiO}_{2}$ requirement is $>0.6$ or the pressure required to maintain oxygenation exceeds $7-8$ $\mathrm{cm}$ of $\mathrm{H}_{2} \mathrm{O}$. Respiratory failure is defined a $\mathrm{paCO}_{2}$ $>60 \mathrm{~mm}$ or $\mathrm{paO}_{2}<50 \mathrm{~mm}$ or saturation $<85 \%$ in $100 \%$ $\mathrm{O}_{2}$ with or without a $\mathrm{pH}$ of $<7.25$. A working algorithm for ventilatory support is given in Fig. 2.

\section{Outcome}

With good intensive care in a neonatal intensive care unit the outcome of neonates with respiratory distress has improved remarkably in the past decade with a survival rate of $>60 \%$ in babies weighing $>1 \mathrm{~kg}$ [9].

\section{Conflicts of Interest}

None identified

\section{References}

1. NNF Recommended Basic Perinatal-Neonatal Nomenclature. In: DK Guha, editors. Neonatology- Principles and Practice. 1st ed. New Delhi : Jaypee Brothers, 1998: 131-2.

2. Silverman WC, Anderson DH. Controlled clinical trial on effects of water mist on obstructive respiratory signs, death rate and necropsy findings among premature infants. Pediatrics 1956; 17: 1-4.

3. Wood DW, Downes' JJ, Locks HI. A clinical score for the diagnosis of respiratory failure. Amer J Dis Child 1972; 123: 227-9.

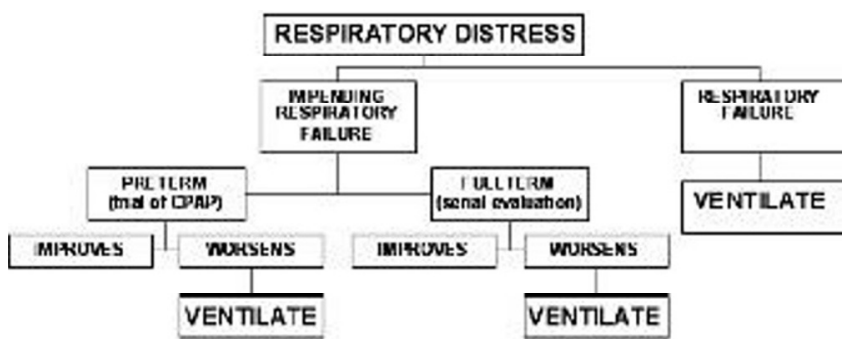

Fig. 2 : Algorithm for ventilatory support

4. Greenough A, Roberton NRC. Acute respiratory disease in the newborn. In: JM Rennie editors. Textbook of Neonatology. 4th ed. China:Churchill Livingstone, 2005: 512-7.

5. Goldsmith JP, Karotkin EH. Introduction to mechanical ventilation. . In : Goldsmith JP, Karotkin EH, editors. Assisted Ventilation of the Newborn. 3rd ed. Philadelphia: WB Saunders, 2003:161-72.

6. Upadhyay A, Deorari AK. Continuous positive airway pressure - a gentler approach to ventilation. Indian Pediatr 2004 ;41:45969.

7. Suresh GK, Soll RF. Current surfactant use in premature infants. Clin Perinatol 2001; 28: 671-93.

8. Stevens TP, Blennow M, Soll RF. Early surfactant administration with brief ventilation vs. selective surfactant and continued mechanical ventilation for preterm infants with or at risk for respiratory distress syndrome. Cochrane Database Syst Rev 2004; 3:CD003063.

9. Mathur NB, Garg P, Mishra TK. Predictors of fatality in neonates requiring mechanical ventilation. Indian Pediatrics 2005; 42:645-51. 